УДК 636.4.082

(C) 2012

Бірта Г. О., доктор сільськогосподарських наук,

Бургу Ю. Г., кандидат сільськогосподарських наук

Вищий навчальний заклад Укоопспілки «Полтавський університет економіки і торгівлі»

\title{
ВІДГОДІВЕЛЬНІ, ЗАБІЙНІ ТА М'ЯСО-САЛЬНІ ЯКОСТІ СВИНЕЙ РІЗНИХ НАПРЯМІВ ПРОДУКТИВНОСТІ
}

Рецензент - доктор сільськогосподарських наук, професор В. П. Рибалко

\begin{abstract}
В успішній реалізації м'ясної проблеми в краӥні важливе значення надавалося і повинно надаватися інтенсифікації галузі свинарства, спрямованої, передусім, на підвищення фактичної продуктивності тварин, зниження собівартості та покращзання якості вироблюваної свинини. Серед ефективних прийомів, що сприяють досягненню високої продуктивності свиней, особливе місие належить впровадженню науково-обтрунтованої системи розведення, шео базується на максимальному використанні наявних у кожному регіоні порід, спеціалізованих типів і ліній, чіткого взаємозв'язку племінних і товарних господарств, раціонального викорис-

тання явища гетерозису, а також створення тваринам оптимальних умов годівлі й утримання.
\end{abstract}

Ключові слова: порода, годівля, утримання, забійні якості, прирости жсивої маси, морфологгічний склад туш, індекс м'ясності, калорійність.

Постановка проблеми. Крім генетичної обумовленості та факторів зовнішнього середовища на якість свинини суттєвий вплив здійснюють також вік, жива маса тварин, особливості їі відгодівлі, транспортування і забою. Ці фактори можуть виступати в якості ефективних прийомів цілеспрямованого управління формуванням якості туш та виходу м'яса і сала.

За однакових умов годівлі свині окремих генотипів по-різному використовують енергію корму. Тварини сального напряму продуктивності краще перетравлюють і використовують жирову й вуглеводну частину раціону. Тому вони вже у 4-5 місяців починають інтенсивніше осалюватись і згодом знижують прирости, а м'ясо-сальні та м'ясні породи краще перетравлюють білкову частину раціону, через що темпи вищих приростів розтягуються на пізніші періоди росту. Відтак, ефективність у збільшенні живої маси й використанні корму у них вища. М'ясні породи свиней вибаглишіві до протеїнового живлення, зате краще від інших свиней засвоюють азот корму.

Аналіз основних досліджень і публікацій, яких започатковано розв'язання проблеми. Вплив годівлі та утримання на ріст і розвиток тварин може мати двоякий характер: недогодівля викликає уповільнення росту, недорозвинення, зниження продуктивності; надмірна годівля прискорює ріст і розвиток тварин. Висвітлюючи питання про вплив умов годівлі необхідно розрізняти: загальний рівень живлення, його повноцінність, структуру раціонів (співвідношення в них грубих, концентрованих і соковитих кормів) і розподіл поживних речовин по періодах росту тварин.

Світовий досвід розвитку галузі свинарства свідчить: процес у підвищенні продуктивності та зниженні собівартості свинини на 60-65\% (а то й більше) визначається науково обгрунтованою годівлею. При цьому максимально можливу продуктивність одержують тільки при концентратній біологічно-повноцінній годівлі. Аналіз свідчить, що за середньодобових приростів у межах 600-800 г свинина завжди буде високоякісною, рентабельною й потрібною на внутрішньому та зарубіжному ринках [1].

Як доводить практика останніх років, не завжди $є$ виправданим бажання багатьох товаровиробників прискорити період відгодівлі свиней за рахунок використання зарубіжних кормових добавок (передусім, хімічного походження) для одержання тисячограмових середньодобових приростів. Ферментні препарати значно підвищують фізичний рівень тварин, однак м'язова i жирова тканини в їх організмі не встигають досягти повного фізіологічного дозрівання. В результаті одержують водянисту, бліду свинину, що погано зберігається. За даними фізикохімічних досліджень, процес гліколізу в повному обсязі проходить лише в м'язах умовно нормальних туш [3].

Мета досліджень і методика їх проведення. Експериментами передбачалося провести порівняльне вивчення відгодівельних, забійних і м'ясо-сальних якостей свиней великої білої породи вітчизняної (ВБУ - І група) і зарубіжної (ВБЗ II група) селекції, а також миргородської (М - III група) та полтавської м'ясної (ПМ - IV група) при чистопородному розведенні, але за різних 
рівнів відгодівлі до живої маси 100 і 125 кілограмів.

Відгодівельні якості помісного молодняку вивчали за такими показниками:

- середньодобовий приріст за період відгодівлі, г;

- вік досягнення тваринами живої маси $100 \mathrm{i}$ 125 кг, дні;

- затрати корму на 1 кг приросту, корм. од.

Забійні й м'ясо-сальні якості тварин визначалися за показниками: передзабійна маса, кг; забійна маса, кг; забійний вихід, \%; довжина напівтуші, см; товщина шпику, мм; площа «м'язового вічка», см$^{2}$; вихід м'яса і сала в туші, кг і \%.

Результати досліджень. При відгодівлі на раціонах, типових для багатьох господарств, середньодобові прирости чистопородного молодняку різних порід дорівнювали в середньому 330 грамів. Живої маси 100 кг за такої годівлі тварини досягли в середньому за 322,8 дні, витрачаючи на кожний кілограм приросту 7,61 кормових одиниць. Дещо кращими за відгодівельними якостями при цьому рівні годівлі були тварини миргородської породи, які виявилися більш пристосованими до низького рівня годівлі. Живої маси 100 кг вони досягли за 321,3 дні при середньодобових приростах 337 г і затраті на 1 кг приросту 7,12 кормових одиниць. Тварини інших порід мали порівняно нижчі показники, хоча суттєвої різниці між ними не встановлено.

При забої піддослідних тварин живою масою 100 кг істотної різниці за масою парної туші також не виявлено, - вона знаходилася в межах 67,1-68,3 кілограмів.

Найменшою товщина шпику була у підсвинків великої білої породи зарубіжної селекції (31,6 мм) та полтавської м'ясної породи (31,7 мм), а найбільшою у їх аналогів миргородської породи 35,4 міліметра.

За виходом м'яса в туші кращими виявилися тварини великої білої породи II піддослідної групи $(51,2 \%)$, а сала більше було у їх аналогів миргородської породи (43,8 мм). Слід зауважити, що за такого рівня годівлі вихід м'яса в тушах коливався в межах 44,4-51,2 відсотків, що пояснюється особливістю організму свині після 6-місячного віку збільшувати відкладання жирової тканини.

При середньому рівні годівлі, який сприяв одержанню середньодобових приростів 600 г і більше, піддослідний молодняк живої маси 100 кг досягав на декілька місяців раніше. Кращими за відгодівельними якостями були підсвинки м'ясної та універсальних порід. Вони вірогідно на 15,2-19 днів раніше свиней миргородської породи досягали живої маси 100 кг, мали на 7285 г більші середньодобові прирости і на $0,31-$ 0,35 корм. од. менше витрачали кормів на 1 кг приросту.

Свині великої білої породи зарубіжної селекції характеризувалися найнижчою товщиною шпику (25,8 мм) і мали найбільшу довжину напівтуші (95,1 см).

Вірогідної різниці за виходом кісток у тушах піддослідних тварин не встановлено: він коливався в межах 11,4-11,8 відсотків. Що ж до виходу м'яса, то цей показник виявився найвищим у тварин II і IV піддослідних груп, відповідно: 62,8 та 60,8 відсотка. За виходом сала в туші $(34,3 \%)$ лідирували підсвинки миргородської породи. Найтовщий шпик мали свині даної породи при різних рівнях відгодівлі. Свині полтавської м'ясної породи мали найтонший шпик, а тварини великої білої породи української та зарубіжної селекції мали проміжні показники.

При середньодобових приростах 250-350 г тварини полтавської м'ясної породи характеризувалися найтоншим шпиком (31,6 мм), хоча свині великої білої породи майже не відрізнялися за цим показником (31,7-32,1 мм). У миргородських свиней товщина шпику дорівнювала 35,9 мм. Збільшення середньодобових приростів до 600-800 г призводило до зменшення товщини шпику в усіх піддослідних групах. Що стосується відмінностей між породами, то найтонший шпик був у полтавської м'ясної породи, а найтовщий у миргородської (різниця - 2,2 мм). Найближчими за цим показником до полтавської м'ясної породи виявилися свині великої білої породи зарубіжної селекції.

Як свідчать повідомлення окремих авторів [2], кореляція між виходом м'яса в туші та площею «м'язового вічка» знаходиться в межах 0,450,46 , площею сала - 0,5-0,6 й індексом м'ясності - 0,55-0,77. Індекс м'ясності має також високу кореляцію 3 фактичним співвідношенням сала $\mathrm{i}$ м'яса $(\mathrm{r}=0,74)$, виходом сала $(\mathrm{r}=0,73)$ i виходом м'яса в туші $(\mathrm{r}=0,68)$.

Значний взаємозв'язок цих ознак вказує на те, що за ними можна робити об'єктивний висновок про м'ясність свиней.

Аналіз проведених досліджень із вивчення м'ясних якостей свиней показав, що площа «м'язового вічка» у тварин усіх піддослідних груп за типового рівня відгодівлі якісно поступалась тваринам, які відгодовувалися за більш високих середньодобових приростів. Площа «м'язового вічка» за типового рівня годівлі була 
на рівні від 26,1 до $27,2 \mathrm{~cm}^{2}$ у 100 кг і від 27,9 до $29,6 \mathrm{~cm}^{2}-$ у 125 кг.

При забої в 100 кг індекс м'ясності, який показує відношення площі «м'язового вічка» до площі підшкірного сала, що прилягає до нього, даючи змогу визначити співвідношення м'яса та сала в туші, був найбільший у свиней полтавської м'ясної породи $(0,87)$, хоча різниця, порівняно $з$ тваринами інших груп, була незначною.

Найвищою енергетичною цінністю характеризувалося м'ясо тварин миргородської породи $(133,9$ 140,6 ккал), різниця 3 полтавською м'ясною породою виявилася незначною (3,7-2,5 ккал).

За середнього рівня годівлі відбувалися зміни в напрямі збільшення площі «м'язового вічка»: у тварин миргородської та великої білої породи української селекції цей показник при забійній масі 100 кг збільшився на 2,1-2,8 см², а у полтавської м'ясної та великої білої породи зарубіжної селекції - на 4,9-6,7 $\mathrm{cm}^{2}$ і, відповідно, на 2,4$3,0 \mathrm{~cm}^{2}$ та 5,9-6,7 см² при забійній масі 125 кілограмів.

Це свідчить про більшу вимогливість свиней II та IV піддослідних груп до умов годівлі.

Індекс м'ясності був найбільшим у тварин II та IV груп, який при середньому рівні годівлі дорівнював більше одиниці.

Найвищою калорійністю характеризувалося м'ясо тварин миргородської породи як при середньому, так і при інтенсивному рівнях годівлі, відповідно: 130,6 і 138,2 ккал і 129,4 і 137,8 ккал.

\section{БІБЛІОГРАФІЯ}

1. Акімов С. В. Ефективність використання кормів свинями полтавсько-білоруської селекції / С. В. Акімов, Н. М. Опришко // Свинарство. 1993. - Вип. 49. - С. 35-38.

2. Бузик В.A. Мясо-сальные качества свиней разных весовых категорий : бюл. научн. работ
Найменш калорійним було м'ясо свиней полтавської м'ясної та великої білої порід зарубіжної селекції. Збільшення середньодобових приростів призводило до зменшення калорійності м'яса.

Дисперсійний аналіз впливу рівня годівлі на індекс м'ясності показав, що найбільший вплив на індекс м'ясності умов годівлі спостерігався у свиней великої білої породи зарубіжної селекції (76,8 \%) при забої в 100 кг та 75,4 \% - при забої в 125 кг; дещо поступались їм свині полтавської м'ясної породи: 62,2 та 60,1% відповідно. Найменше рівень годівлі впливав на індекс м'ясності туш свиней миргородської породи - 29,7-32,0 \%. Вони характеризувалися найбільшими показниками залишкової дисперсії, що включає вплив усіх інших факторів, окрім головного (в даному випадку - рівня годівлі).

\section{Висновки:}

1. Результати, отримані при відгодівлі свиней на рівні 250-350 г середньодобових приростів, підтвердили нівелювання генетичних можливостей свиней різних напрямів продуктивності за недостатнього рівня годівлі, передусім це стосується свиней м'ясних генотипів.

2. Спостерігалася пряма залежність між середньодобовими приростами піддослідних свиней та індексом м'ясності. Збільшення площі «м'язового вічка» в групах тварин, вирощених із вищими середньодобовими приростами, вело до збільшення індексу м'ясності.

ВИЖ / В. А. Бузик, М. П. Карт. - 1989. - С. 93. 3. Диденко Л. А. Особенности формирования мясо-сальной продуктивности у свиней разных генотипов / Л. А. Диденко, В. Е. Мазур // Актуальные вопросы обеспечения АПК: Тезисы докл. XX конф. молодых учених. - 1996. - С. 12. 